\title{
BIOACTIVITY ANALYSIS of Annona glabra L. SEED EXTRACTS FOR WOOD PROTECTION AGAINST TERMITES (Cryptotermes cynocephalus Light. AND Coptotermes curvignathus Holmgren.)
}

\author{
Trisna Priadi ${ }^{* 1}$, Nurul Chotimah ${ }^{1}$, and Agus Ismanto ${ }^{2}$ \\ ${ }^{1}$ Department of Forest Products, IPB University \\ J1. Ulin, Kampus IPB Darmaga Bogor 16680, Indonesia \\ ${ }^{2}$ Center for Standardization of Sustainable Forest Management Instruments, \\ Ministry of Environment and Forestry \\ Jl. Gunung Batu No 5, Bogor, West Java, Indonesia
}

Received: 27 August 2020, Revised: 24 July 2021, Accepted: 14 September 2021

\begin{abstract}
BIOACTIVITY ANALYSIS of Annona glabra L. SEED EXTRACTS FOR WOOD PROTECTION AGAINST TERMITES (Cryptotermes cynocephalus Light. AND Coptotermes curvignathus Holmgren.). Pond apple (Annona glabra L.) belongs to the family of Annonaceae. The seed of $A$. glabra contains bioactive substance that is toxic to some organisms, however the effectiveness to control wood degrading termites has not yet been scientifically reported. This research analyzes the efficacy of $A$. glabra seed extract to wood degrading termites. Seed extraction was conducted using $\mathrm{n}$-hexane and ethyl acetate. The paper disc test showed that the extract of A. glabra is toxic to Cryptotermes cynocephalus (dry-wood termites) and Coptotermes curvignathus (subterranean termites). The higher extract concentration (up to 63\%) resulted in a higher termite mortality (up to 100\%) and lower weight loss of paper sample (less than 1\%). Ethyl acetate extract of $A$. glabra seeds has a better toxicity effect than n-hexane extract against dry wood termites and subterranean termites.
\end{abstract}

Keywords: Annona glabra, biodeterioration, dry-wood termite, efficacy, subterranean termite

ANALISIS BIOAKTIVITAS EKSTRAK BIJI Annona glabra L. UNTUK PERLINDUNGAN KAYU DARI RAYAP PERUSAK KAYU (Cryptotermes cynocephalus Light. DAN Coptotermes curvignathus Holmgren). Sirsak. butan (Annona glabra L.) tergolong family Annonaceae. Biji A. glabra mengandung bahan bioaktif yang bersifat racun bagi beberapa organisme, namun belum ada laporan ilmiah terkait efektivitasnya dalam mengendalikan

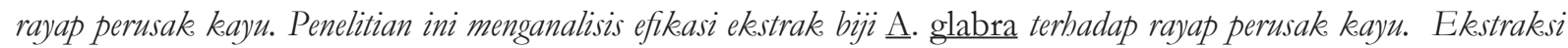
serbuk. biji dilakukan menggunakan pelarut $n$-heeksan dan etil asetat. Metode uji dengan kertas berbentuk disc menunjukan bahwa ekstrak biji $\underline{\mathrm{A}}$. glabra bersifat racun bagi Cryptotermes cynocephalus (rayap kayn kering) dan Coptotermes curvignathus (rayap tanah). Semakin tinggi konsentrasi ekstrak (bingga 63\%) mengakibatkan mortalitas rayap yang semakin tinggi (bingga 100\%) dan kebilangan berat kertas uji yang semakin kecil (kurang dari 1\%). Ekstrak etil asetat

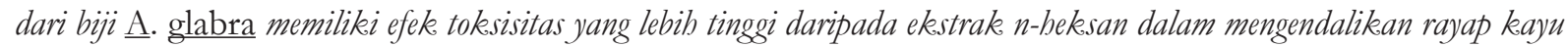
kering dan rayap tanah.

Kata kunci: Annona glabra, biodeteriorasi, efikasi, rayap kayu kering, rayap tanah

*Corresponding author: trisnapriadiipb@yahoo.com 


\section{INTRODUCTION}

Wood is a strong, renewable, and decorative material (Wang, Toppinen \& Justin, 2014), however wood is susceptible to biodegradation that requires preservation. The durability of wood is mainly influenced by the extractive contents (Rizanti et al., 2018). The availability of non-durable woods in the market was more than durable woods (Muslich \& Rulliaty, 2013). The most wood degrading organisms found in buildings is termites (Hasman, Muin \& Taskirawati, 2019), such as dry-wood termites and subterranean termites. Coptotermes is a widespread termites, which is one of the most wood degrading organisms such as $C$. curvignathus (Scheffrahn et al., 2015).

In the tropical regions, the biodeterioration rate is higher than in temperate regions (Gonzalez, Gould, Hudak, \& Hollingsworth, 2008). Therefore, wood preservation and modification are important elements to increase the service life of buildings, furniture and other wood products. Wood preservation generally uses chemicals that are toxic to degrading organisms, but wood preservatives must meet user-safe and environmentally friendly requirements. The use of natural preservatives whose main substances are derived from plants has been discussed by Gonzalez-Laredo Rosales-Castro, Rocha-Guzman, GallegosInfante, Jimenez, and Karchesy (2015), which are more environmentally friendly than synthetic preservatives.

Annonaceae generally contains acetogenins that has a broad range of insecticidal bioactivities (Isman \& Seffrin, 2014). The seed extracts of $A$. squamosa and $A$. muricata have repellent effects on Coptotermes gestroi (Acda, 2014). A. glabra is from the family of Annonaceae, which produces several secondary metabolites that have antifungal (Rocha, Matsumoto, Lombardi, \& Lima, 2017), larvicidal and insecticidal activities (Mohankumar, Shivanna, \& Achuttan, 2016). In general, the seed extracts contain more potent substances than the extracts from other plant parts (Saripalli \& Dixit, 2016). The use of A. glabra seed extracts for controlling wood destroying organisms has not been widely studied. This preliminary study aimed to analyze the efficacy of $A$. glabra seed extract on wood-destroying termites.

\section{MATERIALS AND METHOD}

\section{A. Preparation of Seed Powder}

The seeds of pond apple (A. glabra L.) were obtained from the Center for Plant Conservation-Bogor Botanical Gardens Indonesian Institute of Sciences. The seeds were grounded into powder and screened to the size of 40-60 mesh. The moisture content of seeds was measured based on TAPPI Standard $\mathrm{T} 12$ 0s-75. The powder sample of seeds $( \pm 2$ g) was weighed and oven-dried at $103 \pm 2{ }^{\circ} \mathrm{C}$ to a constant weight. The moisture content was calculated from the sample weight difference before and after drying that is expressed as the percentage from the dry weight of sample (Elinge et al., 2012). The moisture content was determined from three replication tests.

\section{B. Extraction}

The extraction of $A$. glabra seed powder was carried out using cold-soaking maceration method (do Prado Ribeiro et al., 2013) with some modification. This research implemented two solvents in the extraction know as n-hexane and ethyl acetate. The powder was soaked in the solvent at a ratio $1: 3(\mathrm{w} / \mathrm{w})$ at room temperature $\left(27^{\circ} \mathrm{C}\right)$ for 24 hours and was stirred several times. This extraction was conducted three times. The solvent was evaporated using a rotary evaporator at $60^{\circ} \mathrm{C}$ and $400 \mathrm{mmHg}$ for \pm 1 hour. Furthermore, the extracted content was determined by taking $5 \mathrm{ml}$ extract solution into a petri dish and weighed. Some extract solution was dried in an oven at $103 \pm 2^{\circ} \mathrm{C}$ until constant weight. The dry extract was cooled in a desiccator for 15 minutes, then weighed again to get the dry weight of the extract. The extracted content was calculated based on Equation 1, while the extraction yield was calculated using Equation 2. 
$E=\frac{W_{2}-W_{0}}{W_{1}-W_{0}} \times 100$

where:

$\mathrm{E}=$ extract content $(\%)$

$\mathrm{W}_{0}=$ weight of petri dish (g)

$\mathrm{W}_{1}=$ weight of petri dish and extract solution before drying (g)

$\mathrm{W}_{2}=$ weight of petri dish and dry extract after drying (g)

$Y=\frac{T E}{D P} \times 100$

where:

$\mathrm{Y}=$ yield $(\%)$

$\mathrm{TE}=$ total weight of extract $(\mathrm{g})$

DP $=$ oven dry weight of powder $(\mathrm{g})$

\section{Preparation of Preservative Solution}

The extract solution was diluted using distilled water in five concentration levels with the addition of $1 \mathrm{ml}$ of tween 80 as an emulsifier at each concentration (Table 1). Furthermore, the extract solutions were used in the bioactivity test against dry wood termites and subterranean termites.

\section{Bioactivity Test Against Termites}

The efficacy of $A$. glabra seed extract was tested using filter paper disc method as described by Ismanto and Darmawan (2014). The dry filter paper discs ( $5 \mathrm{~cm}$ diameter) were dipped in some extract solutions, except the control paper that was not treated. After airdrying to a constant weight ( \pm 15 days) $\left(\mathbb{W}_{1}\right)$, every paper disc was fed to 25 workers of dry wood termites Cryptotermes cynocephalus and 50 workers of subterranean termites Coptotermes curvignathus separately in $7 \mathrm{~cm}$ diameter petri dishes, and 5 tires replicates. Weekly observations were conducted until the end of the test which lasted 4 weeks. The test paper was cleaned, air-dried and weighed $\left(\mathrm{W}_{2}\right)$. The paper-weight loss and termite mortality were calculated using Equations 3 and 4.

$W L=\frac{W^{1}-W^{2}}{W_{1}} \times 100$

where:

$\mathrm{WL}=$ weight loss $(\%)$

$\mathrm{W}_{1}=$ paper weight before test $(\mathrm{g})$

$\mathrm{W}_{2}=$ paper weight after test $(\mathrm{g})$

$M R=\frac{D}{N} \times 100$

where:

$$
\begin{aligned}
\mathrm{MR} & =\text { termite mortality }(\%) \\
\mathrm{D} & =\text { number of termite death } \\
\mathrm{N} & =\text { initial number of termites }
\end{aligned}
$$

\section{E. Data Analysis}

The data of termite mortality and paper weight loss were analyzed descriptively and presented in tables or graphs using Microsoft Excel 2010 software. The effect of preservative concentration on termite mortality and paper weight loss were analyzed based on Completely Randomized Design (CRD) using Statistical Analysis System (SAS) program 9.1.3. When the analysis of variance resulted in a significant influence, then Duncan test was conducted.

Table 1. Extract concentrations of $A$. glabra seeds in paper disc test

\begin{tabular}{llcc}
\hline Treatments & Dilution & \multicolumn{2}{c}{ Extract Concentration (\%) } \\
\cline { 3 - 4 } & & n-hexane & Ethyl acetate \\
\hline C (control) & & 15 & 0 \\
T1 & 31 & 19 \\
T2 & $4 \mathrm{ml}$ extract $+16 \mathrm{ml}$ aquadest & 47 & 38 \\
T3 & $8 \mathrm{ml}$ extract $+12 \mathrm{ml}$ aquadest & 63 & 57 \\
T4 & $12 \mathrm{ml}$ extract $+8 \mathrm{ml}$ aquadest & 79 & 76 \\
T5 & $16 \mathrm{ml}$ extract $+4 \mathrm{ml}$ aquadest & \\
\hline
\end{tabular}




\section{RESULT AND DISCUSSION}

\section{A. Seed Extraction of $A$. glabra}

The extraction used seed powder of $A$. glabra at $4.9 \%$ moisture content. The yield of extraction with n-hexane solvent was higher than that of ethyl acetate, which was $32.14 \%$ and $18.41 \%$, respectively. These results are in accordance with previous research by Komansilan, Abadi, Yanuwiadi, and Kaligis (2012) who mentioned that the seeds of Annona muricata Linn. produced more n-hexane extract than ethyl acetate extract. Furthermore, after evaporation, the extracted content of $A$. glabra seeds in $\mathrm{n}$-hexane solution was $79 \%$, which was lower than that in ethyl acetate solution (95\%). This higher concentration of ethyl acetate extract had a darker color (brown) than that of n-hexane extract (yellow).

\section{B. Bioactivity Test of $A$. glabra Extract to Wood Degrading Termites}

The use of n-hexane and ethyl acetate extracts from $A$. glabra seeds caused the mortality of up to $100 \%$ of C. cynocephalus (dry wood termites) and C. curvignathus (subterranean termites), while the termite mortality in the control samples were 13\% (C. cynocephalus) and 30\% (C. curvignathus) (Figures 1 and 2). This indicated that the extract of $A$. glabra seeds

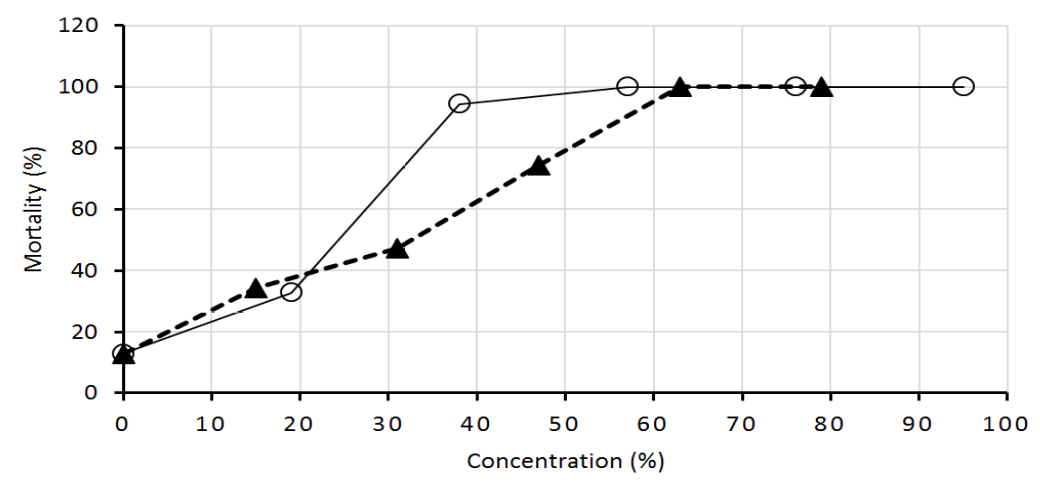

Remarks :

Figure 1. The mortality of C. cynocephalus (dry wood termites) in the test of A. glabra seed extract

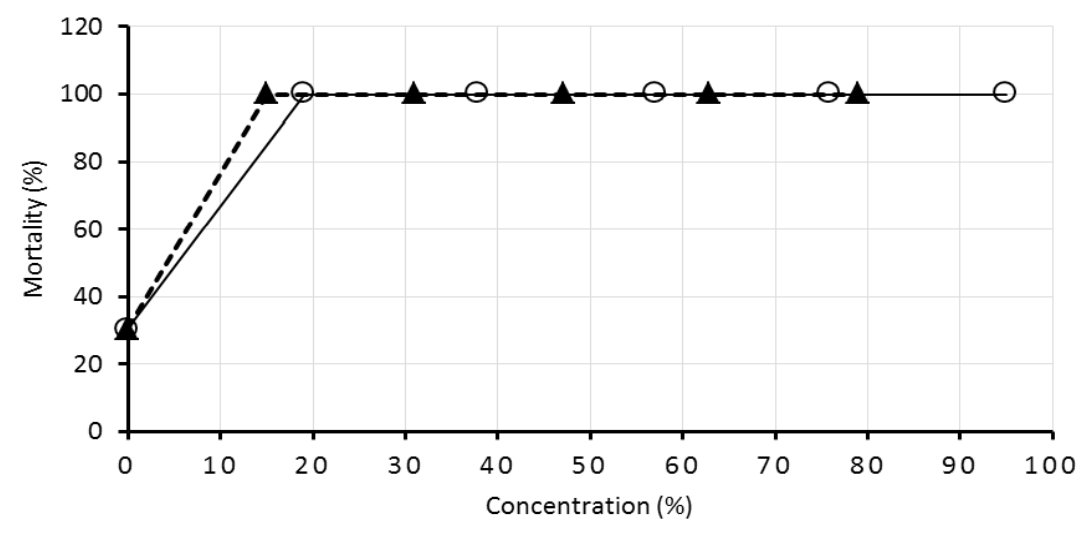

Remarks : $\quad$ - - $\mathbf{- 1}$ n-hexane extract $\quad$ Ethyl acetate extract

Figure 2. The mortality of C. curvignathus (subterranean termite) in the test of $A$. glabra seed extract 
contain toxic substance to these main wood degrading termites. The mortality of dry wood termites (DT) reached 100\% in the extract concentration of $A$. glabra seeds in n-hexane and ethyl acetate at a minimum of $63 \%$ and $57 \%$ respectively. Furthermore, the mortality of subterranean termite (ST) reached 100\% when using a lower minimum concentration of n-hexane extract than the ethyl acetate extract, which were $15 \%$ and $19 \%$, respectively.

The mortality of C. curvignathus termite has reached $100 \%$ at a lower extract concentration than that of C. cynocephalus termite. This indicates the subterranean termites were more sensitive to the toxic substance of $A$. glabra seeds than the dry wood termites. Although this research has not analyzed the main substances of A. glabra seed, the previous findings showed possible toxic substances that could be cultivated from the seeds for further uses mainly in controlling termites attack. The seed extract of A. glabra contained squamocin, asymycin, and acetogenin compounds, which were insecticidal and vermicidal. These bioactive compounds can inhibit the growth, eating activities, or cause the death of insects (Gallardo Aragon, Tormo, Blazquez, Zafra-Polo, \& Cortes, 1998). The insecticidal effect of Annonaceae is mainly caused by the substance of acetogenins that act on mitochondria inhibiting the NADH -ubiquinone oxidoreductase, which cause the death of the insects (Krinski, Massaroli, \& Machado, 2014). Moreover, Darmawan and Ismanto (2016) reported that the main active compounds of $A$. glabra seed extract were 9-octadecenoic acid (oleic acid) and 13-docosenoic acid or erucic acid. This extract caused the mortality of Eurema sp. larvae.

The analysis of variance (ANOVA) resulted that the concentration of both extract solutions significantly affected the mortality of dry wood termites and subterranean termites at 95\% confidence interval. On the other hand the type of extract solution affected differently the mortality of dry wood termites. Further Duncan test showed that the use of n-hexane extract and ethyl acetate extract at concentration of
$15 \%$ and $19 \%$ respectively caused significantly higher mortality of dry wood termites and subterranean termites than that were in the controls.

Based on the mortality value in this test, the required concentration of $\mathrm{n}$-hexane and ethyl acetate extracts of $A$. glabra seed to control dry wood termite were $63 \%$ and $38 \%$, respectively. On the other hand, the concentration of n-hexane and ethyl acetate extracts to control subterranean termites were $15 \%$ and $19 \%$ respectively. In addition to mortality, the value of paper weight loss is an important indicator of termite reaction in the efficacy test of $A$. glabra seed extracts. The weight loss of the test paper treated with $A$. glabra seed extracts was smaller than that without treatment (control). This is evidence that $A$. glabra seed extract can withstand the attack of dry wood termites and subterranean termites (Figure 3 and 4).

The analysis of variance showed that the concentration of both extract solutions significantly affected the weight loss of paper disc at 95\% confidence interval. The Duncan test revealed that the application of n-hexane extract solution and ethyl acetate extract solution from $A$. glabra seeds at concentration of $15 \%$ and $19 \%$ resulted in significantly lower paper weight loss values than that of the control due to dry wood termites (Figure 3). The paper weight loss was lower as the concentration of the extract was higher in the solution. The use of n-hexane extract and ethyl acetate extract at concentration of $31 \%$ and $38 \%$ can inhibit the attack of dry wood termites (C. cynocephalus) from being less than $2 \%$ of the paperweight loss.

The concentration of extract solutions from A. glabra seeds significantly affected the weight loss of test paper attacked by subterranean termites (C. curvignathus) at 95\% confidence interval, while the type of extracts solutions did not significantly affect the weight loss (Figure 4). The treatments of n-hexane extract and ethyl acetate extract at concentrations of $15 \%$ and $19 \%$ respectively resulted in a significantly lower paper weight loss than that of the 


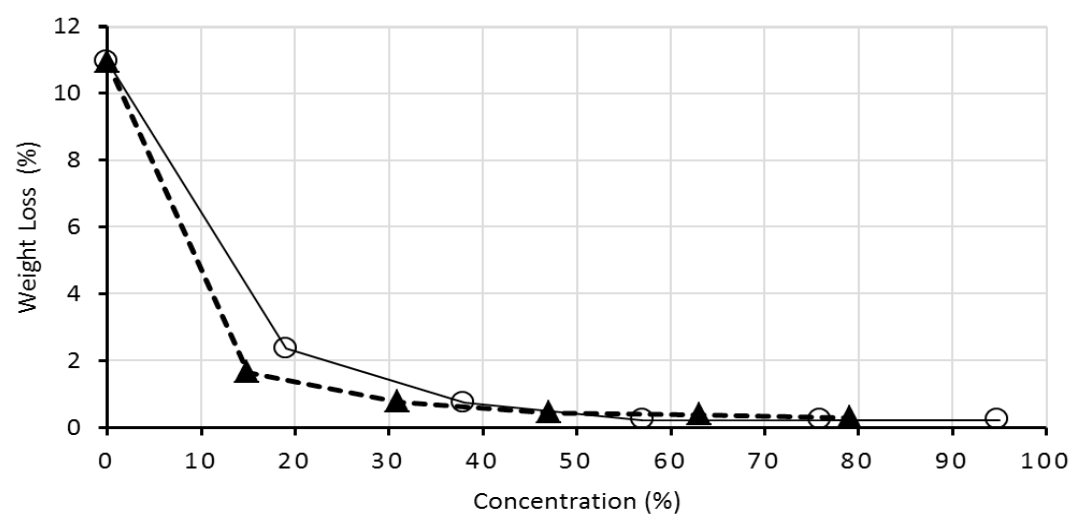

Remarks : - - - - n-hexane extract $\quad$ - Ethyl acetate extract

Figure 3 The paperweight loss due to dry-wood termite attack in the test of A. glabra seed extract

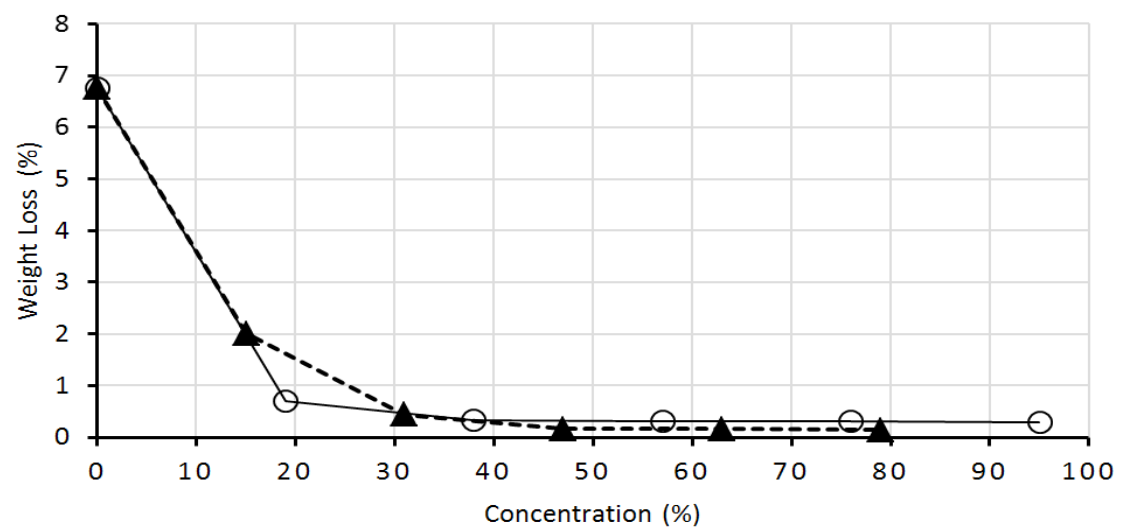

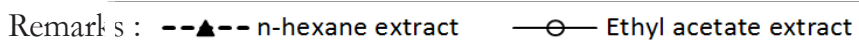

Figure 4. The mortality of $C$. curvignathus (subterranean termite) in the test of $A$. glabra seed extract

control. Based on the value of the paperweight, the n-hexane extract and ethyl acetate extract at concentrations of $31 \%$ and $19 \%$ respectively increased well the resistance from subterranean termites to be less than $1 \%$ of the paper weight loss.

Considering the results of termite mortality and paper weight loss analyses the concentrations of n-hexane and ethyl acetate extracts from $A$. glabra seeds for controlling dry wood termites are $63 \%$ and $38 \%$, respectively; while for controlling subterranean termites are 31\% and $19 \%$, respectively. The results of this research also showed that ethyl acetate extract from $A$. glabra seeds had a better toxicity effect than the n-hexane extract in controlling dry wood termites and subterranean termites because the required concentration was lower than that of n-hexane extract. This is consistent with the report of Elango et al. (2012) that ethyl acetate extracts from some medicinal plants caused higher mortality of Coptotermes formosanus than the hexane extracts. Ethyl acetate and n-hexane solvents have different polarity. Ethyl acetate is semi polar solvent, while $\mathrm{n}$-hexane is non-polar solvent. Different polarity solvents can affect the type and quantity of resulted substances (Rohmah et al. 2020). Moreover, different 
type and quantity substances can affect the protection against termites.

\section{CONCLUSION}

The higher concentration of $A$. glabra seed extract in $n$-hexane and ethyl acetate solutions resulted in higher termite mortality and lower paper loss values. The $\mathrm{n}$-hexane extract from $A$. glabra seeds at concentration of $63 \%$ and $31 \%$ can control dry wood termites and subterranean termites respectively. On the other hand, the ethyl acetate extract required $38 \%$ and $19 \%$ concentration respectively, to control dry wood termites and subterranean termites. Therefore, A. glabra seed extract has the potential to be developed as an anti-termite substances.

\section{REFERENCES}

Acda, M. N. (2014). Repellent effects of annona crude seed extract on the Asian subterranean termite Coptotermes gestroi Wasmann (Isoptera: Rhinotermitidae). Sociobiology, 61(3), 332-337. doi://10.13102/sociobiology.v61i3.332-337.

Darmawan, U. W., \& Ismanto, A. (2016). Mortality of yellow butterfly (Eurema sp.) larvae due to pond apple (Annona glabra L.) seed extract application. Jurnal Penelitian Hutan Tanaman, 13(2), 157-164. doi://10.20886/ jpht.2016.13.2.157-164.

do Prado Ribeiro, L., Vendramim, J. D., Bicalho, K. U., dos Santos Andrade, M., Fernandes, J. B., de Andrade Moral, R., \& Demétrio, C. G. B. (2013). Annona mucosa Jacq. (Annonaceae family): A promising source of bioactive compounds against Sitopbilus zeamais Mots. (Coleoptera: Curculionidae). Journal of Stored Products Research, 55, 6-14. doi://10.1016/j. jspr.2013.06.001.

Elango, G., Rahuman, A. A., Kamaraj, C., Bagavan, A., Zahir, A. A., Santhoshkumar, T., Marimuthu, S. Velayutham, K., Jayaseelan, C., Kirthi, A. V., \& Rajakumar, G. (2012). Efficacy of medicinal plant extracts against formosan subterranean termite, Coptotermes formosanus. Industrial Crops and Products, 36(1), 524-530. doi://10.1016/j.indcrop.2011.10.032.

Elinge, C. M., Muhammad, A., Atiku, F. A., Itodo, A. U., Peni, I. J., Sanni, O. M., \& Mbongo, A. N. (2012). Proximate, mineral and antinutrient composition of pumpkin (Cucurbita pepo L.) seeds extract. International Journal of Plant Research, 2(5), 146-150. doi://10.5923/j. plant.20120205.02.

Gallardo, T., Aragon, R., Tormo, J. R., Blazquez, M. A., Zafra-Polo, M. C., \& Cortes, D. (1998). Acetogenins from Annona glabra seeds. Phytochemistry, 47(5), 811-816. doi://10.1016/ S0031-9422(97)00780-2.

Gonzalez, G., Gould, W. A., Hudak, A. T., \& Hollingsworth, T. N. (2008). Decay of aspen (Populus tremuloides Michx.) wood in moist and dry boreal, temperature, and tropical forest fragments. AMBIO: A Journal of the Human Environment, 37(7), 588-597. doi://10.1579/0044-7447-37.7.588.

Gonzalez-Laredo, R. F., Rosales-Castro, M., Rocha-Guzman, N., Gallegos-Infante, J. A., Jimenez, M. R. M., \& Karchesy, J. J. (2015). Wood preservation using natural products. Madera y Bosques, 21, 63-76. doi://10.21829/ myb.2015.210427.

Hasman, A. E., Muin, M., \& Taskirawati, I. (2019). The diversity of termite species in residential land with various building ages classes, Perennial, 15(2), 74-82.

Isman M.B., \& Seffrin R. (2014). Natural insecticides from the Annonaceae: A unique example for developing biopesticides. In Singh D. (Eds) Advances in Plant Biopesticides. Springer, New Delhi. doi://10.1007/978-81-322-2006-0_2.

Ismanto, A., \& Darmawan, U. W. (2014). The efficacy of organic pesticide of neem seed (Azadirachta indica Juss.) against dry-wood termite Cryptotermes cynocephalus Light. In Lee, S. S., Mas'ud, A. F., Siregar, C. A., Pratiwi, Mindawati, N., Turjaman, M., Krisdianto, Krisnawati, H., Siregar, I. Z., Laba, W., Mardiastuti, A., Wahyudi, I., (eds.), Celebrating a 100-year Forestry Research in Indonesia:Forestry Research for Sustainable Forest Management and Community Welfare. Proceedings of the $2^{\text {nd }}$ INAFOR 2013. 2013 August 27-28. (pp. 755-761), Jakarta.

Komansilan, A., Abadi, A. L., Yanuwiadi, B., \& Kaligis, D. A. (2012). Isolation and identification of biolarvacide from soursop (Annona muricata Linn.), seeds to mosquito (Aedes aegypti) larvae. International Journal of Engineering and Technology, 12(03), 28-32.

Krinski, D., Massaroli, A., \& Machado, M. (2014). Insecticidal potential of the annonaceae family plants. Revista Brasileira de Fruticultura, $36(1), \quad 225-242 . \quad$ doi://10.1590/S010029452014000500027. 
Mohankumar, T. K., Shivanna, K. S., \& Achuttan, V. V. (2016). Screening of methanolic plant extracts against larvae of Aedes aegypti and Anopheles stephensi in Mysore. Journal of Arthropod-Borne Diseases, 10(3), 303-314. https://jad.tums.ac.ir/index.php/jad/issue/ view/31.

Muslich, M., \& Rulliaty, S. (2013). The durability of fifty wood species in field and marine tests. Jurnal Penelitian Hasil Hutan, 31(4), 250-257. doi://10.20886/jphh.2013.31.4.250-257.

Rizanti, D. E., Darmawan, W., George, B., Merlin, A., Dumarcay, S., Chapuis, H., Gerardin, C., Gelhaye, E., Raharivelomanana, P., Sari, R. K., Syafii, W., Mohaed, R., \& Gerardin, P. (2018). Comparison of teak wood properties according to forest management: Short versus long rotation. Annals of Forest Science, 75, 39. doi://10.1007/s13595-0180716-8.

Rocha, G. S., Matsumoto, R. S., Lombardi, A. T., \& Lima, M. I. S. (2017). Potential effects of fungicide and algaecide extracts of Annona glabra L. (Annonaceae) on the microalgae Raphidocelis subcapitata and on the oomycete Pythium. Anais da Academia Brasileira de Ciências, 89(3), 2101-2111. doi://10.1590/00013765201720160040 .

Rohmah, J., Saidi, I. A., Rini, C. S., Masyitha, D. A., Ramadhani, D. N., \& Wulandari, H. P. (2020). Antioxidant activity of etanol, etil acetate, and n-heaxane extracts of garlic (Sesbania grandiflora (L.) Pers.) by DPPH (1,1-Diphenyl-2-picrylhydrazyl) method. Research Chemistry Journal, 5(1), 67-85.
Saripalli, H. R., \& Dixit, P. K. (2016). Studies on morphological features and biological activities of the genus Annona of Ethiopia, N. E. Africa with a special emphasis on graviola: A review. International Journal of Science and Research, 5(2), 821-827. https:// www.ijsr.net/archive/v5i2/3021602.pdf.

Scheffrahn, R. H., Carrijo, T. F., Křeček, J., Su, N. Y., Szalanski, A. L., Austin, J. W., Chase, J. A., \& Mangold, J. R. (2015). A single endemic and three exotic species of the termite genus Coptotermes (Isoptera, Rhinotermitidae) in the New World. Arthropod Systematics \& Phylogeny, 73(2), 333-348.

TAPPI (The Technical Association of the Pulp and Paper Industry. (1996). TAPPI Test Methods. Atlanta: TAPPI Press.

Wang, L., Toppinen, A., \& Justin, H. (2014). Use of wood in green building: a study of expert perspectives from the UK. Journal of Cleaner Production, 65, 350-361. https:// www.sciencedirect.com/journal/journal-ofcleaner-production/vol/65/suppl/C. 